\title{
CORRIGENDUM
}

\section{Love, Struggle, and Compromises: The Political Seriousness of Nairobi Underground Hip Hop. - CORRIGENDUM}

\author{
RaShelle R. Peck
}

doi:10.1017/asr.2017.143. Published by Cambridge University Press, April 2018.

In the reference list of this article (Peck 2018) the first name of one of the references was misspelled. The correct reference is:

Mose, Caroline. 2013. "'Swag' and 'Cred': Representing Hip-hop in the African City.” Journal of Pan African Studies 6 (3): 106-32.

The author regrets the error.

\section{Reference}

Peck, RaShelle R. 2018. Love, Struggle, and Compromises: The Political Seriousness of Nairobi Underground Hip Hop. African Studies Review 61 (2): 111-133. doi:10.1017/asr.2017.143. 